\title{
Constructing the Model of Aboriginal Tribal Social Enterprises from the Concept of Social Economic Enterprises
}

\author{
Hsiao-Ming Liu ${ }^{1}$, Shang-Yung Yen ${ }^{2}$ \\ ${ }^{1}$ Ph.D. Program of Business, Feng Chia University, Taiwan (R.O.C.) \\ ${ }^{2}$ Professor of MBA, Feng Chia University, Taiwan (R.O.C.) \\ Correspondence: Hsiao-Ming Liu, No. 100 Wenhwa Rd., Seatwen, Taichung City40724, Taiwan (R.O.C.).
}

\author{
Received: April 30, 2018 \\ doi:10.5539/ibr.v11n7p76 \\ Accepted: June 3, $2018 \quad$ Online Published: June 15, 2018 \\ URL: https://doi.org/10.5539/ibr.v11n7p76
}

\begin{abstract}
Taiwan's aboriginal tribes have long been affected by political forces and market economy model, and the aboriginal people living in remote mountainous areas with lack of information have met with a lot of economic and social problems and challenges such as loss of land and traditional culture, aging population and stagnation of tribal industry development. Therefore, the original self-sufficient tribes began to prone to "poverty", and this is one of the most critical social issues for Taiwan to cope with. The purpose of this paper is to discuss the concept of "social economy" in the aboriginal tribes, to develop and restore the sharing economic cooperation model, to increase collective interests and to set up tribal social enterprises, so as to address the crucial social issues.

This study will adopt the method and experience of socio-economic analysis to study the action plan of Seediq, a division of Taiwanese aboriginals, and their experience of social and economic organization and operation, and reflection on the social enterprise system. The main research is to explore the social economy in the Meixi tribe, the status quo and future development, and how to employ social innovation to promote the tribal social enterprise planning and business model.
\end{abstract}

Keywords: social economy, aboriginal tribes, social enterprises, share, collective interests

\section{Introduction}

Taiwan is an island with multi-ethnics, the first peoples to live in this island were the "Aboriginal", most of the aboriginal people living in the high-altitude and low development of remote mountainous areas. Most of the tribes live under the norms of "self-supplied" and "mutual cooperation" and "sharing." The aboriginal tribes had no currency for trading; they just exchanged labors and foods to carry out transactions. With the development of Taiwan's political and economic changes, the tribes had a huge impact from the introduction of market economy model. The norms of the tribe have been destroyed; local work opportunities are getting fewer and fewer; many young people are leaving the tribes for the cities to pursue economic interests and improve their family life. The tribes are turning into an aging population. Intercultural education, traditional culture and tribal languages are getting lost with time, and poverty turns out to be conspicuous. In addition, the land they live on began to drain because of market transactions, and, thus, sustainable development seems to be impossible.

Aboriginal population as of the end of March 2017 is 554,585, about 2.26\% of the total population of Taiwan. The average income for working aboriginal people is NT\$30,005 per person per month while average working income for the Taiwanese is NT\$39,238, about 1.3 times of the working income of the aborigines. As of December of 2016, the labor force participation rate for the aboriginal people was $60.96 \%$, higher than the rate $58.80 \%$ for the Taiwanese. The unemployment rate for the aboriginal people is $3.94 \%$ as opposed to $3.79 \%$, the rate for Taiwanese, which is $0.15 \%$ lower.

In brief, the paper is aimed to make the aboriginal tribes think deeply as to find back the norms of the original self-sufficiency, mutual cooperation and sharing of living standards, with the use of innovative methods for social enterprises to establish a commonly shared economic model so as to eliminate poverty and improve the economic lives of the aboriginal people in Taiwan. 


\section{Literature Review}

\subsection{Social Economic}

The idea of social economy is produced under the influence of unsymmetrical development between the capitalist market economy and the society. The combination of the third sector and social economy plays an important bridge between the public and private departments, as the role of the fill (Zeng Zifeng, 2003: 32). In 1848 Friedrich Wilhelm Raiffeisen set up a plan in Germany for raising money to help poor farmers, but the result was not disastrous as he found that people were facing many social and economic problems which had better be resolved first, and the best policy was to make them on their own to help themselves. So he based on the principle of self-help and set up the first savings society in the world (Zheng Wenliang, 2007). The goal for social economy is to make the disabled in society have more opportunities to obtain goods and services, to protect equal opportunities for the disadvantaged to participate in economic operation of the society (Social Economy Europe, 2013), with a view to creating jobs for the local markets financially and successfully, and training the people who had previously been excluded from the society (Amin et al., 2002: 31).

At present, the main research on social economy in Taiwan is based on the "cooperative" type of economic organization. In the 1970s by the French scholars began to implement a specific policy or organizational type, and then spread to other European countries and Canada, Latin America, which covers the organization: cooperatives, mutual organizations, associations, foundations and other four categories, the EU will these Organizations are collectively referred to as social economic enterprises by the European Union. In other words, "socio-economy" is composed of a series of special organizations which do not belong to the public sectors and have the ability for autonomous management and each member of the organization has equal right and obligation to observe the democratic method of one person one vote for decision-making as regards the distribution of earnings, the operation and expansion of the organization and the use of surplus ( either for the internal members or for the purpose of public welfare as the nature of the mission of the organization ). Social economies are particularly targeted at rural areas, health, sustainable development and other issues which cannot be solved through the self-adjustment mechanism of the market or the overall economic policy, and, therefore, the relevant initiatives and policies come into being. Social economy can reconcile multiple issues such as the economy, society, and finances of an organization. It can also reduce information asymmetry and establish local networks so that social and economic networks can operate effectively and solve many social problems.

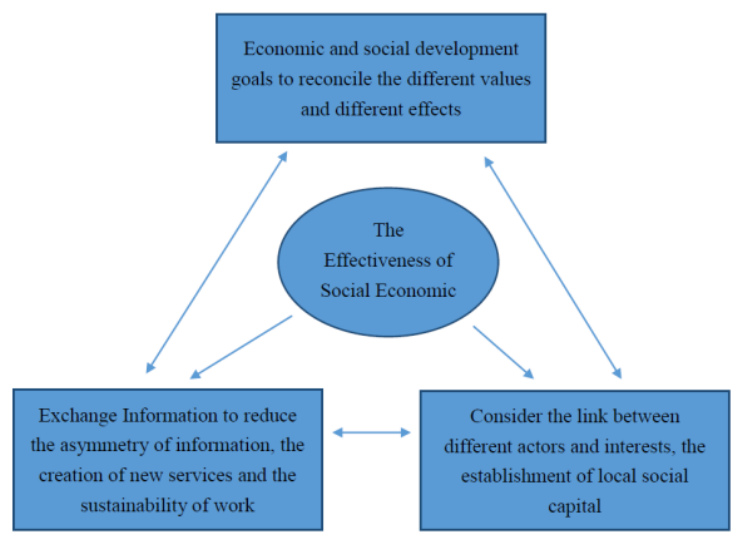

Figure 1. Effectiveness of socio-economic organizations

Source: Greffe 2007: 97

\subsection{Social Enterprises}

Non-profit organizations are marching to the direction of industrialization, with social-oriented purposes and economic means of operation, to achieve the social purpose of serving the people and address the dilemma in which the government fails to provide adequate welfare services. This type of socio-economic organization is called "social enterprise" (Liang Kailin, 2016: 16). The concept of social enterprise plays a special and innovative role in the welfare network. The concept of social enterprise is the type of the third sector organization that combines the different modes of operation. These different modes of operation include cooperation in the production process and the spirit of social enterprise which governs the economy's goods and services and allows more citizens to participate in the production process (Gonzales, 2007). The mode of 
operation for a social enterprise is a co-construction concept, which is a service project constructed with the needs of the people and the participation of the people in the service network. (Liang Kailin, 2016: 17).

\subsection{Seediq}

As a division of the Atayal family, the Seediq regard themselves as different from the Atayal people. In order to reveal their subjective consciousness of the tribe, the Seediq clan made a request to the government for an official name of their tribe, and in April 2008, Seediq was officially named for the fourteenth tribe of Taiwanese aboriginal people.

The Seediq tribe is mainly living in Renai Township, Nantou County, to the upper reaches of the Zhuoshuixi River hinterland of central Taiwan. Due to dispersion of the people and traffic inconvenience, the communities of the society are rather closed and have formed the unique tribal culture and languages. There are three different languages for the Seediq.

In the traditional culture of the Seediq, the most intense ethnic characteristics is the tattoo culture, face tattoo is the symbol for Seediq adults and ethnic groups, and it would be difficult for one to live in the Seediq society without tattoo on the face. The tribe is convinced that only the person with face tattoo can, after his death, return to Utux's side through the "Hakaw Utux / Hako Utux (Bridge of Life, "Zuling Bridge"). This is the instruction from the ancestors and will be followed by the Seediqs for life. The tribe of the Seediq is the traditional form of agricultural/ hunting society, which is based on Gaya and tribal consciousness. Gaya is the law and social norms of the Seediq, and the law and norms are descended from generation to generation. It is also known as ancestral training, and tribal consciousness is founded on the basis of Gaya.

\subsection{Meixi Tribe}

Meixi tribe is located in Nanfeng Village, Renai Township, Nantou County, including the Nanshan Creek, the Catholic Church, and three settlements with a population of 900 Seediqs. Meixi tribe has a wealth of Seediq culture, its natural environment and diverse ecological species, especially the butterfly ecology. The tribal industry is dominated by agriculture (tea and coffee), and has recently been committed to promoting tribal sightseeing (cultural and ecological tours). At present, the main organizations within the tribe are Nanfeng Village Office, Nanfeng Community Development Association, Taiwan Aboriginal Horde Promotion and Culture Foundation, East Coast Tribe Industry Promotion and Development Association, Meixi credit union and so on. In recent years, the tribe has been actively engaged in cultural preservation and reconstruction, retaining traditional festivals and rebuilding the unique family houses of the Seediq. These buildings use traditional methods with slate, logs, bark and vines, and prove to be cool, dry and comfortable.

\section{Research Method and Purposes}

This study explored the construction of the tribal social enterprise model in light of socioeconomic concepts. The Meixi tribe was used as a case study. A literature review, case studies, and interviews were examined to collect detailed information concerning the major challenges facing Taiwan's aboriginal groups and potential solutions.

\subsection{The Literature Analysis Method}

Analyze related articles relating the study to explore and grasp the past situation of the subject. The case of the Meixi tribe is based on the analysis of the documents of the Meixi tribe in order to understand the relevant tribal culture, history, industry and social economic organization, and further as the basis for a case study action plan

\subsection{The Case Study Method}

Case study method is a supplementary research method for collecting the relevant information and theory used in practical research. The researcher must be rooted in the study of the context of the time and space with holistic description of the entity, in order to construct, understand and describe the purpose of research on social entities with historic, locale and comprehensive views. (Jiang Mingxiu, 1997, 128 129)

\subsection{Research Purposes}

To explore the feasibility evaluation and model establishment of the socio-economic model in the aboriginal tribal roots.

Aboriginal peoples' development of independent economic models combined with innovative business models of social enterprises, establishing new business models that belong to aboriginal tribes.

To propose strategies for solving the fundamental problems of the aboriginal tribes and establish solutions to improve the problems of the aboriginal society. 


\section{Research Results}

\subsection{The Status Quo and Future Development of Socio-Economy in the Meixi Tribe.}

Among the organizations of social management in the tribe, the Meixi credit union is the most institutionalized organization with scale; indeed, it is the Meixi tribe financial center. "This is the tribal bank; it is indispensable." Meixi credit union was established in 1955 as Taiwan's first aboriginal credit union with more than two hundred household members (almost every household is a member).

Members shall deposit the monthly savings of at least NT\$ 100 per month. And the shares cannot be withdrawn so as to develop the habit of compulsory savings. Once there is any need, such as entrepreneurship, schooling, medical treatment, etc., the member can apply to the Among the organizations of credit union in the tribe, the Meixi credit union is the most institutionalized organization with scale; indeed, it is the Meixi tribe financial center. for a loan as social assistance, and procedures are extremely simple.

The credit union is a self-help cooperative group established to improve the life and welfare of the members and promote the development of the community. The principle of saving and mutual financing both implemented and the minor deposits for the whole loan with the periodic payment are intended to encourage the majority of national savings. The credit union was established only for the service of the members with emphasis on consumer loans, and it has proved to be of great help to development of civilians financing and stability of the society. Recently tribes have tried to set up agricultural production cooperatives for collective production and sales, and the source of funds is also from the credit union. In brief, the socio-economic development in the Meixi tribe is extremely active and continuous mode and scale seems to be normal and forward-looking.

Although the credit unions cannot prevent the occurrence of poverty, at least they can help the poor cope with the urgent economic crisis and promote long-term social participation. And the credit union is a community-based nonprofit organization; it is not only a financial organization, but also a community development organization. In United States and United Kingdom the credit union have been used to promote the development of disadvantaged communities with many successful precedents. Moreover, the credit union prove to be effective to accumulate personal capitals and promote social participation. Most of Meixi people fully trust the credit union as it has accompanied the tribal people passing through the long and difficult years.

\subsection{The Tribal Social Enterprise Planning and the Establishment of Business Model}

The study indicates that the Meixi peoples used to have their own way to produce and sell their agricultural products individually and could not make adequate profits at all as most of the profits were taken by the wholesalers. Nowadays they started to produce pesticide-free products with the concept of eco-agriculture and have won wide acclaim from the market. And they are in need of more capitals to improve their producing equipment and environment, and it is high time for them to make good use of the credit union for raising capitals, as shown in Figure 2:

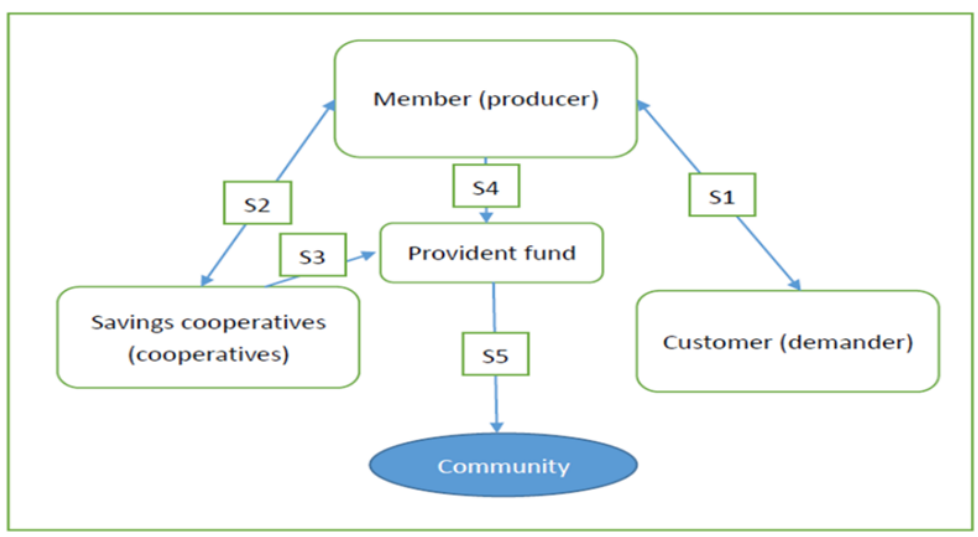

Figure 2. Meixi Tribe Social Enterprise Agriculture Production and Operation

The credit union are composed of the members who own the land or have the wish to participate in agricultural production cooperates. The credit union provides capitals (S2) with low interests for the members to improve the production environment in order to meet the needs of ecological agricultural production.

As the credit union is a national organization scattering everywhere in Taiwan, its sales channels other than the 
traditional accesses, surely help promote marketing. The credit union can effectively grasp the external (customers) demand (s1), and the credit union will produce products according to the demand at the contractual agreement price (s1), and then the credit union will select the producer (s2). The producers must also carry out field management according to the relevant regulations. In the production process, the demander can actually understand the production process in the production area and participate in the production management process (the concept of the holiday farmer), and may require the producer to provide the production history. After the product is sold by the member, the product will be handed over to the purchaser by the credit union (cooperatives), and the product will be paid by the credit union. After the payment is made to the credit union, the credit union will pay the producer money based on the contract with the members. And the producer shall deduct the production cost and life needs and pay back to the credit union for the loan.

While the credit union cooperates with the demander (customers), the producer shall pay a portion of the price to the credit union(S3), which is used as insurance for the disaster risk and reserved for social welfare, scholarship or cultural education, etc. (s5). In addition, credit union should provide professional education and training for producers and ensure the open, transparent and regular exchange of information needed to ensure fair opportunities for the members.

A credit union is a not-for-profit organization that does not aim for profit. It has the value of its existence and it also bears the task that needs to be accomplished. Non-profit organizations are socially oriented, and they are essentially service-oriented. In order to respond to changes in the times and the environment, credit cooperatives' service users gradually expand from members to communities and fulfill their social responsibilities. Residents take a new look at the co-operative economy and enable the regional credit unions to perform their social functions and achieve the goals of both economic development and social responsibility.

\section{Conclusion}

The main core spirit of social enterprises is based on public interests and solving social problems, using business operation models, not pursuing maximization of profit value, but aiming at achieving specific economic or social goals, that is, the mission of social enterprises. It is the creation of more "social values" rather than profits as the main appeal. According to the definition of Social Enterprise UK (2012), social values are generated by the contract or procurement process, beyond the direct purchase of products, services or outputs. The benefits of the community. Therefore, aboriginal tribes develop the tribal social enterprise model from the socio-economic concept. The ultimate goal is to use the model of commercial operation and not to maximize the profit value to achieve specific economic or tribal goals.

The tribe is the fundamental foundation of the aborigines, and its industrial development should be based on basic tribal units and tribal consensus, with the concept of common wealth and democratic management to meet the tribe's economic, social and cultural needs and aspirations, and to form an autonomy of a community of social enterprises as a normative and tribal cohesion symbol. It is highly expected that collective planning and management of tribal industry, equality of interests and sound welfare system will soon be realized as a great step to solve the issues of the aboriginal societies in Taiwan.

\section{References}

Alter, K. (2006). Social Enterprise Models and Their Mission and Money Relationships. In A. Nichollsed. Social Entrepreneurship: New Models of Sustainable Social Change, New York, NY: Oxford University Press, pp. 205-232.

Anderson. (1998). The Origins of Postmodernity, London : Verso.

Boschee, J. (1995). Social entrepreneurship. Across the Board, pp. 20-24.

Borzaga \& J. Defourny, (2001). The Emergence of Social Enterprise. London \& New York: Routledge. pp.1-28.

Bellwood, P. (1991). The Austronesian Dispersal and the Origins of Languages. Scientific American July: 88-93.

Battilana, J., Lee, M., Walker, J., \& Dorsey, C. (2012). In search of the hybrid ideal. Stanford Social Innovation Review, 10(3), 51-55.

Defourny, J. (2001). From Third Sector to Social Enterprise. In C. Borzaga \& J.Defourny eds. The Emergence of Social Enterprise, London, UK: Routledge, 1-28.

Ducci, G., Stentalla, C., \& Vulterini, P. (2002). The social enterprise in Europe. International Journal of Mental Health, 31(3).

Defourny, J. (2001). Introduction: From Third Sector to Social Enterprise. The Emergency of Social Enterprise, 
London and New York: Routledge.

Dart, R. (2004). The legitimacy of social enterprise. Nonprofit management and leadership, 14(4), 411-424.

Dees, J. G. (1998). Enterprising Non-Profits: What Do You Do When Traditional Sources of Funding Fall Short? Harvard Business Review, January-February, 5-15.

Dees, J. G., \& Anderson, B. B. (2003). Framing A Theory of Social entrepreneurship: Building on Two Schools of Pracitice and Though. ARNOVA Occasional Paper Series, 1(3).

Cai, Y. J. (2010). Knowledge of the Operation of Taiwan's Aboriginal "Tribal Banks" - The Gula Han Clan of Alababa Bay For example, 7 Taiwan Issue of Aboriginal Studies, 181-208.

Dees, J. G., Emerson, J., \& Economy, P. (2004). Enterprising Nonprofits: A Toolkit for Socail Entrepreneurs, BestWise Publishing Co., Ltd, \& Higb Wiley and Sons Ltd.

Dees, J. G. (1998). The Meaning of 'Social Entrepreneurship', draft report for the Kauffman Center for Entrepreneurial Leadership, Stanford University.

Ducci, M., Gazzano, A., Villani, C., Cela, V., Artini, P. G., Martelli, F., \& Genazzani, A. R. (2002). Membrane integrity evaluation in rabbit spermatozoa. European journal of obstetrics, gynecology and reproductive biology, 102(1), 53-56.

Dai, Y. Y., \& Lin, Y. J. (2007). Promotion of social enterprises to promote employment policy planning proposals. Taipei: Executive Council of the Executive Council of the Executive Yuan.

G.reen, P. (2002). The Co-operative Way towards a New Equilibrium. ICA Review, 95(1).

Gisbosn-Graham, J. K. (2010). Post-Development Possibilities for Local and Regional Development in A. Pike et al.(eds.)Handbook of Local and Regional Developament, 1-17, London: Routledge.

Gisbosn-Graham, J. K. (2009). Socially Creative Thinking or How Experimental Thinking Creates "Other Worlds", November 21.

Huang, Y. X. (2014). Indigenous Peoples' Social Welfare: Problem Analysis and System Construction, Taipei, Futaba.

Kai-Lin, L. (2016). Constructing Utopia Elderly Care Model: A Case Study of the Social Economic Governance Innovation in Bodhi Chang Ching Village. Department of Public Policy and Administration, College of Humanities, National Chi Nan University.

Kerlin, J. A. (2006). Social Enterprise in the United Stated and Europre: Understanding and Learning from the Differences. Voluntas, 17(3), 247-263.

Kingma, B. R. (1997). Public Good Theories of the Nonprofit Sector: Weisbrod Revisited. Voluntas, 8(2), $135-148$.

Lash, S., \& Lury. (2007). Glonal Culture Industry: The Mediation of Things, Cambridge, Polity press.

Lash, S., \& Urry. (1994). Aboriginal of signs and Space. London: Sage.

Lawrwnce, K. (2006). Aboriginal Women Working in Vocational Training and Education: A story from Central Australia. Journal of Vocational Education and Training, 58(4), 423-440.

Liu, Z. H. (2010). The Taiwan Credit Union System and Its Enlightenment. Journal of Anhui Normal University (Humanities and Social Sciences), 38(3), 329-303.

Lin, B., Li, J. M., \& He, X. Y. (1994) World Cooperation Celebrity Biography, Taipei, China Association of Cooperatives, China Association of Cooperatives, Taichung, Republic of China Credit Union.

Mancino, A., \& Thomas, A. (2005). An Italian Pattern of Social Enterprise-The Social Cooperative. Nonprofit Management \&Leadership, 15(3), 357-369.

Mair, J., \& Martí, I. (2006). Social entrepreneurship research: A source of explanation, prediction, and delight. Journal of World Business, 4l(1), 36-44.

Monzon, J. L., \& Chaves, R. (2008). The European social economy: concept and dimensions of the third sector. Annals of Public and Cooperative Economics, 79(3-4), 549-577.

Massarsky, C. W. (2005). Enterprise Strategies for Generating Revenue. In The Jossey-Bass Handbook of Nonprofit Leadership and Management (2nd.ed.), edited by Robert D. Herman \& Associates. San Francisco: Jossey-Bass Publishers. 
Mulgan, G. (2006). The process of social innovation. Innovations: Technology, Governance, Globalization, 1(2), 145-162.

Nyssens, M., Adam, S., \& Johnson, T. (2006). Social Enterprise: At the Crossroads of Market. Public Policies and Civil Society. New York: Routledge.

OECD (1999). Social Enterprises, OECD.

OECD (2001). Corporate Social Responsibility: Partners for Progress, OECD.

OECD ( 2003). The Non-profit Sector in a Changing Economy, OECD

OECD (2003). The Non-profit Sector in a Changing Economy. OECD.

Pelchat, M. C. (2005). Social entrepreneurship in Taiwan: Possibilities and challenges for empowerment. Paper presented at the Fourth ISTR Asia and Pacific Conference. Nov. 16-18, 2005. Bangalore, India.

Pelchat, M. C. (2004). Enterprizing Asian NPOs: Social Entrepreneurship inTaiwan. Paper presented at the Conference of Asian Foundations and Organizations(CAFO).

Shaw, E. (2004). Marketing in the Social Enterprise Context: Is it Entrepreneurial? Qualitative Market Research: A International Journal, 17(3), 194-205.

Social Enterprise London. (2002). Social Enterprise Guide to Health \& Social Care for the Elderly. London: Social Enterprise London.

Saaty, T. L. (1980). The Analytic Hierarchy Process, McGraw-Hill, New York.

Sen, (1999). In A. Nicholls ed. Social Entrepreneurship :New Models of Sustainable Social Change, New York.

Sen, A. (1999). Development as Freedom. Oxford: Oxford University Press.

Scott, A. J. (2000). The Cultural Economy of Cities: Essay on the Geography of mage-Producing Industries, London: Sage.

Tse-Fong, T. (2003). Social Economy and the Development of the Third Sector, Research Bimonthly, 27(6), Research, Development, and Evaluation Commission, Executive Yuan, Taiwan.

Translations by Ian, M. P., Feng, J. J., \& Tang, D. C. (2005). History of World Credit Unions. Taipei: The Republic of China Association for Savings and Savings.

Urry, J. (1990). The Tourist Gaze: Leisure and Travel in Contemporary Societies, London: Sage.

Weisbrod, B. A. (1998). To Profit or not to Profit: The Commercial Transformation of the Nonprofit Sector. Cambridge: Cambridge University Press.

Wallace, S. L. (1999). Social entrepreneurship: The role of social purpose enterprise in facilitating community economic development. Journal of Developmental Entrepreneurship, 4(2), 153-174.

Wang, S. C. (2007). Overview of Taiwan's Aboriginal Economic Policy. Economic Outlook, 113, 83-87.

Wu, Z. S. (2011). "Church and Society: An Analysis of the Religion, Ethnic Group and Currency Network of the Taiwan Stock Exchange Society (1964-1997). "Fu Jen Society Research" inaugural issue number: 73-104.

Yu, Y. M. (2008). The concept of the development of Taiwanese cooperative enterprise strategy. Credit Cooperation, No. 95, 10-21

Zhang, J. X. (2014). Community Services for Credit Unions. Master Thesis of National Jinan International University.

\section{Copyrights}

Copyright for this article is retained by the author(s), with first publication rights granted to the journal.

This is an open-access article distributed under the terms and conditions of the Creative Commons Attribution license (http://creativecommons.org/licenses/by/4.0/). 